\title{
The Federal Income Tax And The Poor: Where Do We Go From Here?
}

\author{
Harvey E. Brazer*
}

In American society being poor and being among the "disadvantaged" mean essentially the same thing. Being poor places one in a position in which his various rights are more likely to be impaired than if he is not poor, simply because, in protecting his rights against infringement, one typically incurs substantial costs. This paper is concerned, therefore, with the position of those who may be classified as "poor" or "near-poor," and whether the federal individual income tax is or may be used as an appropriate and effective instrument for alleviating or even eliminating poverty. Clearly the elimination of poverty will not, in itself, ensure equal access to justice for all. It will, however, bring us closer to realization of that goal. While some will always, by reason of their greater affluence, be more advantaged than others, we must set limits on the degree of economic disadvantage that we are willing to tolerate.

This Article will first review some of the facts of poverty and then consider the case for redistributing income in favor of the poor. It will examine the role of the federal individual income tax in its present form in relieving poverty, and, finally, present and evaluate what appear to be the more promising ways of using the machinery of the income tax to combat the basic disadvantage suffered by people in this country-being poor.

\section{I}

THE NEED FOR A PROGRAM OF DIRECT GOVERNMENT INCOME TRANSFERS

\section{A. A Definition of Poverty and the Poverty Gap}

Poverty may be defined in either relative or absolute terms. If we define the poor as those whose incomes fall, say, below the 20th

* B. Com., 1943, McGill University; A.M., 1947, Ph. D., 1951, Columbia University. Chairman, Department of Economics, University of Michigan. The author is pleased to acknowledge the generous support of the Benjamin Rosenthal Foundation, Inc. and the Social Security Administration. That support made possible much of the research that underlies this paper. The views expressed herein, however, are not endorsed by the Foundation or the Administration. For them the author is solely responsiblc. Gail $R$. Wilensky contributed in a major way to the development of the form and substance of the children's allowance plan set forth in Part III. 
percentile when all families and unrelated individuals are arrayed according to size of income, we have arbitrarily declared that approximately 40 million of our population are poor, and the poor, in this sense, shall always be with us. Our policy objective then becomes that of raising the standard of living of the poor. Alternatively, we may define poverty in terms of a target level of income per family or per person which, though arbitrarily selected, represents a minimum that the conscience of an affluent society is willing to tolerate. This target or poverty benchmark is useful as a policy objective. It should be understood, however, to be only an interim objective at best; the specified "poverty line" would then be subject to regular upward adjustment as prices and productivity rise. A definition of poverty in absolute terms seems preferable, as a policy objective or reference point, because it lends itself to a more readily meaningful calculus in terms of costs and provides a yardstick for progress. 1t nevertheless remains useful and relevant to pose questions periodically as to the welfare of those who are within the bottom fifth, or quarter, or half of the income distribution. And surely, there can be no room for complacency until all Americans are able to live "decently," with dignity and freedom from deprivation.

A measure of poverty that has come into wide use has been developed by the Social Security Administration. ${ }^{1}$ lt is based on the cost per day per family member of an "economy" food plan designed by the Department of Agriculture to be "nutritionally sound." This cost for a nonfarm family of four is approximately 75 cents per person. ${ }^{2}$ Assuming that a poor family should be expected to spend no more than one-third of its income on food, ${ }^{3}$ the minimum income requirement for such a family at 1966 prices is $\$ 3,335$. The figure is adjusted for size of family, age of children, sex and age of head, farm and nonfarm residence, and so forth. The poverty line range for nonfarm families goes from $\$ 1,560$ for a single female under the age of 65 to $\$ 5,440$ for a family of "7 or more" members headed by a male. For farm residents the figures are just under one-third lower. ${ }^{4}$ This poverty index is far from generous, as may be seen from the fact that in 1966 the median income of all four-person families was

1. The Social Security Administration's measures of poverty and low-income are described in detail in Orshansky, Counting the Poor: Another Look at the Poverty Profile, Social Security Bull. Jan. 1965, at 5-10, and Who's Who Among the Poor: A Demographic View of Poverty. Social Security Bull. July 1965, at 3-10.

2. Orshansky, The Shape of Poverty in 1966. Social Security BuLl. March 1968, at 5.

3. Id.

4. For a table of weighted average poverty level incomes for 1966, see id. at 4. 
$\$ 8,340,5$ slightly more than $21 / 2$ times the $\$ 3,335$ poverty line for nonfarm families of that size. Nevertheless, more than 15 percent of the total noninstitutionalized civilian population, 29.7 million out of 193.4 million, were, by this austere standard, classified as poor in $19666^{\circ}$ Of the 29.7 million people 4.8 million were "unrelated individuals," and 24.9 million, 12.5 million of whom were children under 18 years of age, lived as members of two-or-more-person families.?

In the aggregate the difference between money income received by the poor in 1966 and income sufficient to bring all families and unrelated individuals to a level of income equal to the "poverty line"-the so-called poverty gap-has been estimated at \$11 billion." This represents an average of over $\$ 1,000$ for each of the more than 10 million $^{9}$ poor families and unrelated individuals in the United States. In Table 1 we present data on the size of the poverty gap in $1965^{10}$ by number of related children in the family and for unrelated individuals, separately for whites and nonwhites. Two facts stand out most sharply. The median poverty gap for nonwhite families, most of whom are black, at $\$ 1,165$, is almost $\$ 300$ larger than it is for white families. And the size of the poverty gap generally increases as the number of related children in the family rises. For both whites and nonwhites the gap ranges from about two to $21 / 2$ times as large for families with four or more children than it is for those without children. Thus less than $\$ 1,000$ of additional income per family would bring almost three-quarters of the white and two-thirds of the nonwhite childless families above the poverty threshold, but amounts of this size would accomplish this objective for less than one-third of the largest white families and substantially less than one-quarter of the largest nonwhite families.

\section{B. The Face of the Poor and the Need for a Multifaceted Approach}

The years 1959 to 1966 comprised a period of unprecedented growth in the American economy. During this period progress was

5. Id. at 6 .

6. Id. at 6 .

7. U. S. Bureau of the Census, The Extent of Poverty in the United States: 1959 10 1966 , Current Population Reports 12 (Series P-60, No. 54, 1968).

8. Tobin, Raising the Incomes of the Poor, in Agenda For the NATION 104 (K. Gordon ed. 1968). Mollie Orshansky reports a poverty gap of S1I billion for 1965. Orshansky, The Shape of Poverty in 1966, Social Security Bull. March 1968, at 19. If the same figure is applicable to both 1965 and 1966, it may be implied, because the number of poor persons declined between the two years, that the poor in 1966 were somewhat worse off than those considered poor in 1965.

9. See Table 1, infra.

10. The latest year for which the details are available. 
臂

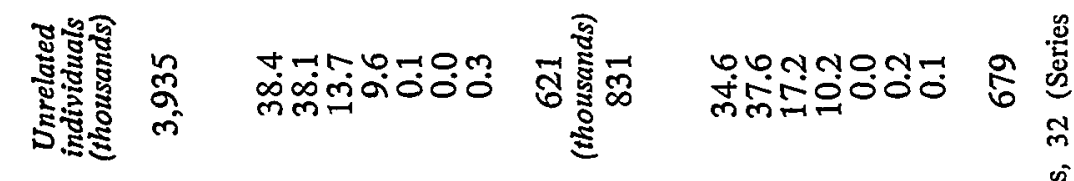

ò वे

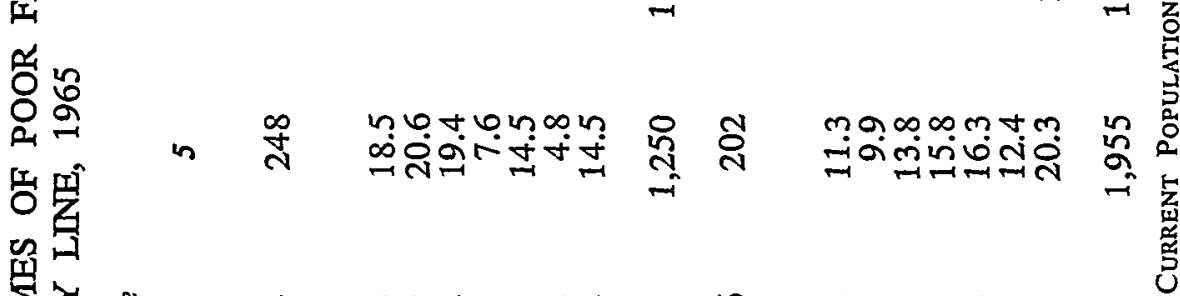

资

疍

$\$$

奥苗

기

造贯

$\exists \mathrm{A}$

련

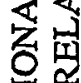

क

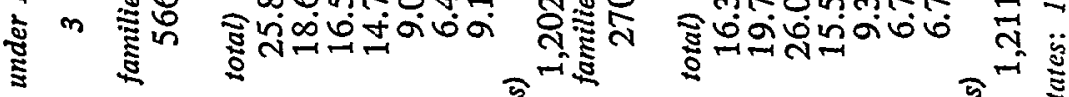

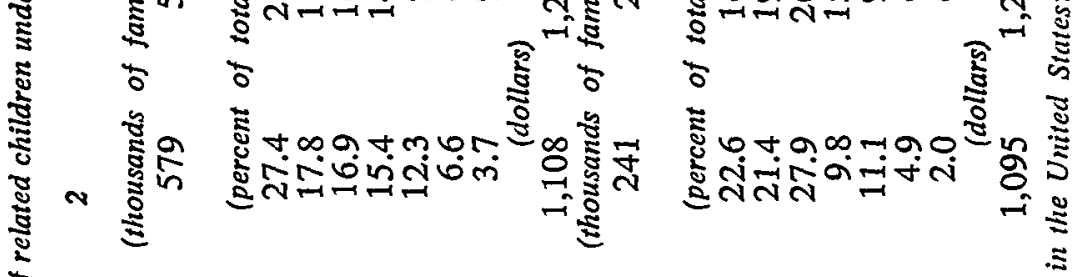

2

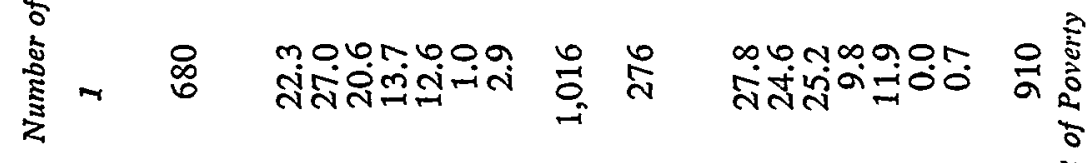

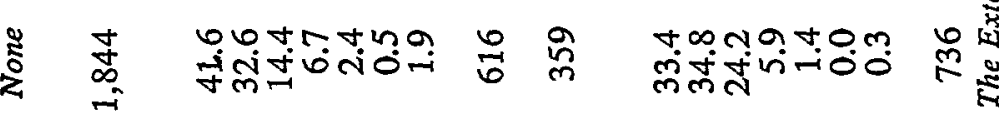

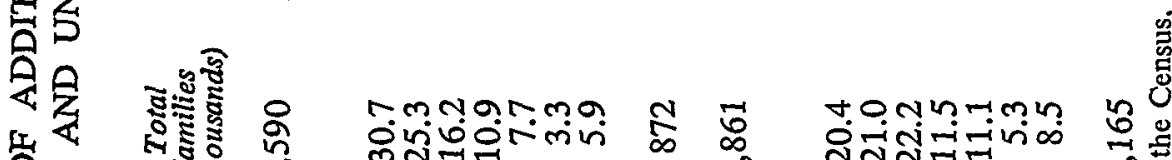

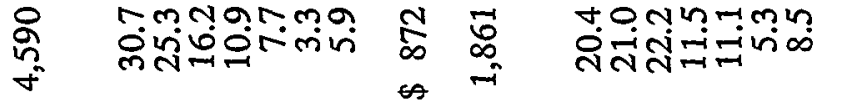

$0 . \dot{\infty}$

占

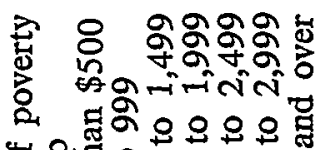

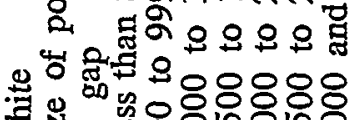
部

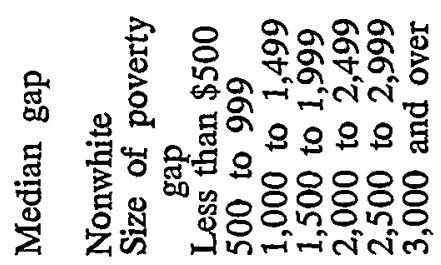

$\cos$

学安 品的宫 荵芯 
made in reducing the number of people living in poverty as we have defined it." In seven years that number was reduced from 38.9 million to 29.7 million, from 22.1 to 15.4 percent of the total population. ${ }^{12}$ But some groups fared much better than others. At the extremes, we find that the number of poor people living in families headed by a white male, the largest single category shown in Table 2 , fell by almost 40 percent beteeen 1959 and 1966, whereas the number living in families headed by a nonwhite female increased by almost onequarter. As may be seen in Table 2, the reduction in the number of children living in poverty was somewhat greater, at 24.8 percent, than for all persons, but the contrast among groups of children was striking. Reflecting improved employment opportunities and the very low level of unemployment experienced by married men in 1966, the number of related children who were members of poor families headed by males dropped over 36 percent and by almost 40 percent in the case of whites. For children of families headed by females, however, the picture was very different: a net increase of 11 percent made up of a decline of 13 percent with respect to whites and a rise of 44 percent in the case of nonwhites. Thus rapid growtl and high employment in the economy, together with public and private training programs and other measures introduced since 1959, appear to have lifted a substantial proportion of the poor above the poverty line. But nearly half , of the poor are still members of families headed by a white male, only 117,000 of whom were unemployed as of March, 1967..13 And nonwhites, particularly those who are in families headed by a female, have gained little since 1959 or have actually lost ground. The hard fact remains that over 60 percent of all persons and more than 75 percent of children in nonwhite families headed by a female were classified as poor in 1966. These proportions are only slightly lower than they were in 1959.

Under present economic circumstances few people are poor because, although able to work, they cannot find a job. Poverty among the gainfully employed, and such persons comprise fully half of all heads of poor families, stems from inadequate training or education, personal disabilities of a physical, mental, or emotional nature, large size of family relative to earning capacity, and, un-

11. In subsequent sections of this paper data on the characteristics of the poor are drawn from Orshansky, The Shape of Poverty in 1966, Soctal SEcuRity Bull., March 1968, at 3-32, unless other sources are specifically cited.

12. These figures do not take into account the rise in the cost of living.

13. See Table 2 and source cited. 


\section{TABLE 2}

INCIDENCE OF POVERTY, BY FAMLY STATUS AND COLOR OF HEAD, 1966 AND 1959

Total

White

Nonwhite

In families with male head

White

Nonwhite

In families with female head

White

Nonwhite

Unrelated individuals

Male

White

Nonwhite

Female

White

Nonwhite

Related children under 18 total

In families with male head White

Nonwhite

In families with female head

White

Nonwhite

$$
\begin{gathered}
1966 \text { (thousands of } \\
\text { persons) }
\end{gathered}
$$

$$
29,731
$$

20,126

9,605

17,644

12,264

5,380

7,267

3,836

3,431

4,820

1,276

1,007

269

3,544

3,019

525

12,503

8,045

5,294

2,751

4,458

2,011

2,447
38,940

28,231

10,709

26,885

19,867

7,018

6,979

4,205

2,774

5,076

1,565

1,161

404

3,511

2,998

513

16,637

12,627

8,756

3,871

4,010

2,311

1,699
Change:

1959 to 1966 (percent)

$-23.6$

$-28.7$

$-10.3$

$-34.4$

$-38.3$

$-23.3$

$+4.1$

$-8.8$

$+23.7$

$-5.0$

$-18.5$

$-13.3$

$-33.4$

+
+

$+0.7$

$+2.3$

$-24.8$

$-36.3$

$-39.5$

$-28.9$

$+11.2$

$-13.0$

$+44.0$

Source: U. S. Bureau of the Census, The Extent of Poverty in the United States: 1959 to 1966, CuRrent Population Reports 14 (Series P-60, No. 54, 1968). 
doubtedly for many Negroes and other deprived minorities, limited opportunity and occupational choice. Approximately one-sixth of all poor persons are members of families lieaded by people aged 65 or over, or are aged unrelated individuals most of whom are no longer in the labor force. Another large group among the poor not in the labor force are the approximately one million female heads of families who are under 65 years of age.

This brief overview of some of the salient characteristics of the poor should suffice to make the point that realization of even so modest a goal as raising the incomes of all families and unrelated individuals to a level above the very spartan poverty line will require a multifaceted approach. The earning capacities of those who can work can be improved by elimination of discriminatory practices in hiring and promotion, by job training programs, by improving worker mobility and placement efforts, by better health care, and by continued economic growth at "capacity" rates accompanied by national unemployment levels of less than 4 percent. Others who are not now in the labor force would be freed to find jobs if child care facilities were vastly expanded and appropriate training provided.

But the earning capacity of many of the poor, particularly those who are already well beyond school age, and even many of those who are still in school but who are growing up under economically and culturally deprived circumstances, is not likely to rise to levels that will permit an escape from poverty. In 1966 more than one-third of all poor families consisted of five or more persons, and for these larger families poverty may be due as much or more to the number of children dependent on the breadwinner as to the inadequacy of his ability to earn income. In addition there are those poor who cannot or should not work, including mothers of young children for whom adequate care cannot be provided, the aged, and those too disabled to work.

Thus even if we could accomplish at once all that might be done to raise the earning capacity of the working poor, elimination of poverty would still require a major program of direct governmental transfers or grants in cash and/or in kind. Without such transfers grinding poverty and its attendant miseries would continue for great proportions of the aged, the disabled, broken families, and families whose heads are industrious but limited in their skills. Moreover, children in these families would be tied to the treadmill of poverty transmitted generation to generation. Children who are inadequately fed, clothed and housed, who grow up with their physical and mental faculties impaired by ill health, without hope or dignity, are likely to 
suffer from insurmountable handicaps on entry into the educational system. Even if that system were all that its critics believe it should be, ${ }^{1+}$ these children might be incapable of acquiring an education that would enable them to escape from poverty and dependency. Income transfers or supplements to earnings are required simply because education, training and other aspects of what Professor Tobin has called the "structural approach" in antipoverty policy, ${ }^{15}$ take a good deal of time to produce results. The poor have no private resources to draw on until employers revamp hiring and promotion policies and procedures, or while training or learning new skills. An educational system divided into 20,000 school districts and structured by teacher training institutions to serve the needs and aspirations of the white middle class will not be fully prepared for at least another generation to cope with the problems involved in imparting to poor childrenand especially poor minority group children-the skills enabling them to climb out of poverty.

\section{The Operation of a Successful Income Supplement Program}

Income transfers may take the form of cash or transfers in kind. The latter have been advocated as a means of ensuring that low income families will have adequate housing, health care and nutrition. ${ }^{16}$ They play a major role in current transfers under public assistance and are justified on the ground that funds paid out would otherwise be wasted through unwise spending by their recipients. It is this attitude, however, that most severely stigmatizes the "welfare family," that most clearly sets it apart as incapable of making its own decisions. Without cash to spend as one pleases there can be little dignity or self-respect in our society, and little prospect for development of a rational consumer mentality. Thus transfers to the poor should take the form mainly or exclusively of cash, supplemented by medicaid and consumer counseling. The failures of public housing, food distribution, and so forth, argue strongly in favor of this position.

Supplements to income, whatever their specific form, should meet several basic criteria. Most important, perhaps, they should be

14. See, e.g.. the provocative and insightful essay on the shortcomings and need for reform of our public schools by Ralph W. Tyler, entitled Investing in Better Schools, in AGENDA FOR THE NAT1ON 207-36 (K. Gordon ed. 1968).

15. Tobin, supra note 8 , at 90 .

16. In the broad sense transfers in kind may be defined to include education, police and fire protection, sanitation services, recreation, and other public services. To the extent that these services are provided to the public in general, without regard to individual or family income, however, 1 prefer to exclude them in the present context. 
regarded as a matter of right, without the stigma of public charity attaching to present forms of public assistance. Means or income tests should be based on self-declarations similar to those applicable to income tax returns and, as in the case of the income tax, the individual should be presumed to be honest until proven otherwise. This implies, of course, the abandonment of the kind of means test now generally used.

Income transfers or grants should not discourage efforts to earn income. Transfers should, therefore, be so structured that they improve the relative income position of the recipient but do not change his rank ordering in the income distribution. ${ }^{17}$ That is to say, within a particular family size group, in order to change his rank in the distribution, a person would have to receive some form of earnings in addition to income transfers.

Abandonment of eligibility requirements, including the means test, as now apply with respect to $A F D C^{18}$ will in itself do much to encourage people to seek jobs, free of the fear that if the job is found and then soon lost, the individual may be worse off than if he had never made the effort to earn income. The form of and conditions attaching to grants should serve to strengthen rather than destroy family ties. Unlike present practices under public assistance, there should be no income premium associated with the breaking up of the family group.

The transfer program should be efficient in the sense that the portion of the cost attributable to benefits accruing to the poor and near-poor should be as nearly equal to the entire amount of the program's cost as is compatible with avoiding effective marginal tax rates $^{19}$ on low-income people so high as to discourage work effort. Obviously no fine line can be drawn here. The income level at which net benefits should fall to zero or below is bound to be arbitrary. Given that the objective of income transfers is to support structural policies designed to eliminate poverty, however, it is this writer's judgment that that level should be somewhere below the median income for each family size.

Poverty, therefore, must be attacked on many fronts. Complementing other policy measures, income supplements will continue indefinitely to comprise a major part of the national effort.

17. In other words, if there are three people, and the poorest of them reccives transfer payments, he should remain third in rank after their receipt.

18. Aid to Families with Dependent Children.

19. The marginal tax rate is merely that rate of income tax that one pays on each increment to income. 
Such supplements can eliminate most or all of poverty as soon as we are willing to implement them adequately. Their supportive role could then be expected to decline for as long as two generations, after which they would be paid primarily to the aged, the disabled, and large, broken families.

\section{THE PRESENT STRUCTURE OF THE INCOME TAX AND INCOME DISTRIBUTION}

The federal individual income tax has been at the center of the stage in most recent discussions of measures designed to supplement the income of the poor ${ }^{20} \mathrm{ln}$ its present form the income tax is widely viewed as a major instrument of income redistribution. Its actual achievement on this score, however, is surprisingly small. The "Gini coefficient" "21 is the most convenient measure of inequality in the

20. For a recent summary of the literature, see C. Green, Negative Taxes and the PoverTy Problem (1967). Among other contributions that have been added since Green's book appeared are: Rolph, The Negative Income Tax, 59 NAT'L TAx Ass'N Proceedings 147 (1966); Tobin, Pechman and Mieszkowski, Is a Negative Income Tax Practical? 77 YALE L.J. 1 (1967); Tobin, supra note 8; Brazer, Tax Policy and Children's Allowances, in Children's allowances and the Economic Welfare of Children (E.M. Burns ed. 1968); and Seltzer, The Personal Exemptions in the Income Tax (1968).

21. Defined as the ratio of the area between the Lorenz curve (depicting the cumulated proportion of total income accruing to the cumulated proportion of income recipients arrayed in ascending order by level of income from lowest to highest) and a diagonal line representing full equality in income distribution to the entire area under the diagonal.

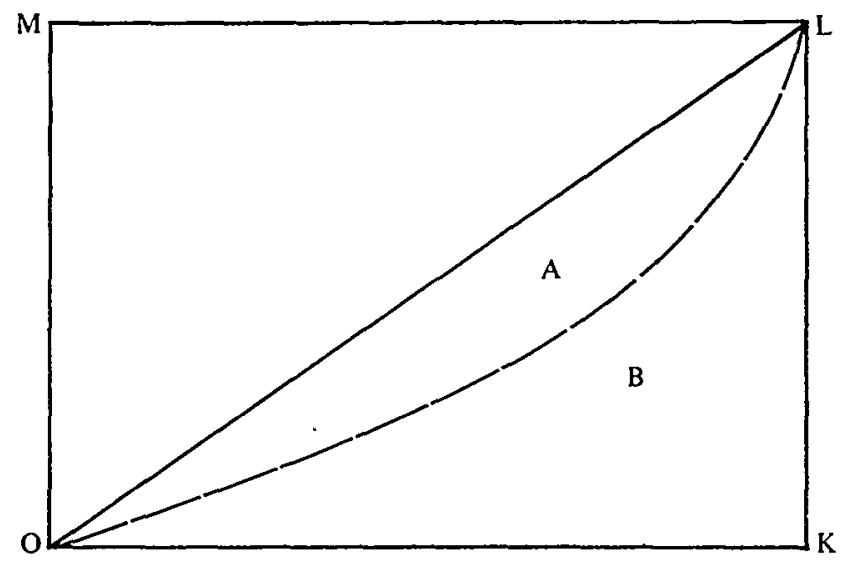

Gini coefficient $=\frac{A}{A+B}$ 
distribution of income. Its limits lie between 0 , when income distribution is fully equal, and 1 , when all income is received by one unit. For 1966 it has been estimated that for all income tax units the before-tax Gini coefficient was equal to .446 . Its after-tax value was .409 , a reduction in the degree of inequality of 8.3 percent. ${ }^{22}$ Thus the relative income position of low-income individuals and families who filed income tax returns in 1966 may be said to have been modestly improved. But the income tax currently adds nothing to anyone's income and therefore accomplishes no improvement in the absolute level of well-being of the poor and near-poor. Moreover a Iarge proportion of poor persons are not accounted for on tax returns, ${ }^{23}$ so that the Gini coefficients cited actually understate inequality in the distribution of income.

There is, however, at least one sense in which the individual income tax, given the structure of tax rates, provides benefits for the poor and near-poor. This is accomplished by means of the tax savings that accrue as a consequence of the existence of the personal exemptions, nonbusiness deductions, the optional or minimum standard deduction, and various allowable exclusions. But except for the minimum standard deduction, the benefits realized by the poor in each instance are but a small fraction of total revenue foregone by the government. In the case of the personal exemptions, for example, in 1966 a total of $\$ 117$ billion was deducted on all returns, $\$ 96.3$ billion on taxable and $\$ 20.7$ billion on nontaxable returns. ${ }^{24}$ If the $\$ 96.3$ billion had been taxed at an average rate of 20 percent (somewhat higher than the average of 19.6 percent on actual taxable income), the increase in revenue realized would have been $\$ 19.3$ billion. Disallowance of the exemptions claimed on nontaxable returns, and addition of the $\$ 400$ to $\$ 500$ million in tax that might have been paid by the 20 million persons who do not appear as exemptions claimed on tax returns, might have increased this figure to about $\$ 21$ billion. To what extent did this reduction in tax liability accrue to Iow-income people? If we assume that all returns which reported Iess than $\$ 3,000$ of adjusted gross income were filed by poor persons we can approximate an answer. On taxable returns with less than $\$ 3,000$ of

22. Pechman and Okner, Application of the Carter Commission Proposals 10 the L'Ilt'd States: A Simulation Study, NAT'L. TAX J. Vol. XX11 (forthcoming).

23. For 1963 an estimated 20.8 million persons were not represented in income tax returns filed. See A. Ott, D. Ott and J.S. Turner, Simulation of Costs of a Negative Income Tax Plan and its Implications for the Poor 3, December, 1968 (unpublished manuscript on file with authors).

24. Internal Revenue Service, U.S. Treasury Dep't, Statistics of 1NCovie - 1966: INDIVIDUAL INCOME TAX RETURNS 7 (1968). 
adjusted gross income $\$ 7.5$ billion was deducted for personal exemptions. At an average tax rate of 15 percent the tax saving would have amounted to $\$ 1.1$ billion. At the outside we might add $\$ 1$ billion in tax that would have been paid if the $\$ 14.4$ billion in exemptions claimed on non-taxable returns with adjusted gross income of less than $\$ 3,000$ had not been allowed, plus perhaps another $\$ 400$ million to take into account tax that might have been due from those not now required to file because their adjusted gross income falls below $\$ 600$ or, for the aged, below $\$ 1,200 .^{25}$ Thus $\$ 2.5$ billion seems a generous estimate of the benefits accruing to the poor. 1t would seem, therefore, to "cost" the federal government more than $\$ 8$ in order to save the poor $\$ 1$ through this route.

Similarly, an increase in the level of the personal exemption appears to be a most costly and unpromising way to improve the wellbeing of the poor. Those who either do not file returns now or who file nontaxable returns would, obviously, gain nothing. For taxable returns with adjusted gross income of up to $\$ 3,000$ a $\$ 100$ increase in the personal exemption would reduce taxable income by less than $\$ 1$ billion and tax liability by about $\$ 150$ million. The revenue loss associated with the increase in exemptions would amount to some $\$ 3$ billion, so that only one-twentieth of the tax saving would accrue to the poor. ${ }^{26}$

Similar analysis with respect to deductions and exclusions would show that the gains in tax saving realized by low-income individuals and families are only a small fraction of the total revenue cost. The one exception, as already noted is the minimum standard deduction of $\$ 200$ for the taxpayer plus $\$ 100$ for each exemption (including his own), up to a maximum of $\$ 1,000 .^{2 \pi}$ The $\$ 350$ million cost of this provision accrues largely to those with incomes under $\$ 5,000$. But even this route will not take us very far. In fact if all taxable returns with adjusted gross income reported in 1966 of less than $\$ 3,000$ were relieved entirely of all tax liability the gain in disposable income would be only $\$ 1.2$ billion, about 6 percent of reported income. ${ }^{28}$

Nor do there appear to be significant gains to be realized by the poor through bold reforms that would broaden the tax base by curtailing or eliminating deductions and exclusions and thus permit major reductions in tax rates. One must conclude, rather, that income tax reform that stops short of providing substantial net payments to

25. INT. Rev. CODE of 1954, \$151.

26. Estimates derived from Statistics of INcove, supra note 24, Table 2.

27. INT. R!:V. Colt: of 1954, \& 141.

28. Statistics of INCOME, supra note 24, at 6. 
the poor and near-poor is simply incapable of making any appreciable inroads on the poverty problem. It certainly cannot do so efficiently, in the sense in which efficiency was suggested ${ }^{29}$ as one important criterion to be met by measures designed to alleviate poverty.

\section{IİI}

\section{ALTERNATIVE FORMS OF NEGATIVE INCOME TAXATION}

This brings us to consideration of the "negative" income tax and the various forms that it might take. Negative income tax is, perhaps, a misleading term, because for most present taxpayers the individual income tax would continue to function as it now does. The tax becomes "negative" only in the sense that the liability of the lowest income recipients becomes negative; that is, they receive a net payment from the Treasury. Most plans would include all persons who met the low income test, some would require major reform of the tax base while others would not, and there are variations as well in the extent to which existing public assistance and social security programs would be supplanted. Space will permit the examination of only two of the plans that have been offered and a somewhat more elaborate version of my earlier proposal that limits the negative income tax to families with dependent children. Most other proposals are, however, essentially variants of the first two.

\section{A. The Credit Income Tax}

EarI Rolph has suggested a form of negative income tax which he calls the "Credit Income Tax." two main ingredients: (1) a system of flat-sum credits to which every person in the country would be entitled, and (2) a general proportional income tax with zero exemptions.' 31 Actually Rolph would provide uniform credits for adults and smaller credits for children which would vary with age, presumably higher credits for older than for younger children. He expressed the view that the adult credit might equal "about $\$ 400$," although recognizing that this would ameliorate but not eliminate poverty. ${ }^{32}$ Thus for a family of two adults and two children the credits might total perhaps $\$ 1,200$ to

\footnotetext{
29. See text accompanying note 19 supra.

30. Tobin, supra note 8 .

3I. Id. at 147.

32. Id. at 149.
} 
$\$ 1.400$. But this is only about 40 percent of the "poverty line" income, ${ }^{33}$ and credits of the suggested size would be too small to supplant AFDC, aid to the blind, the disabled, and the aged in all but the states with the lowest benefits. Nevertheless, even at the suggested level of the credit, it would make substantial inroads into the poverty gap, particularly with respect to the working poor.

If we assume a credit of $\$ 400$ for each adult and an average of $\$ 300$ for each child under the age of 18 , the aggregate amount of credits allowed would be approximately $\$ 52$ billion for adults plus $\$ 21$ billion for children, a total of $\$ 73$ billion. If the net yield to the government from the individual income tax is to be, say, $\$ 67$ billion, then a proportionate tax on income as comprehensively defined, with no exemptions, exclusions, or deductions would have to raise a total of $\$ 140$ billion. Suppose that personal income, broadly defined, is equal to $\$ 700$ billion. Then the uniform tax rate would be 20 percent. Of the gross yield of $\$ 140$ billion the Treasury would receive $\$ 67$ billion and credits would absorb the rest. The effect of the credit income tax on a family of two adults and two children, at various income levels, is illustrated in Table 3 . Net benefits begin at $\$ 1,400$ when income before tax or credits is zero and fall off as income rises until they disappear when income reaches $\$ 7,000$. Beyond that level a

TABLE 3

EFFECTS OF CREDIT INCOME TAX ON DISPOSABLE INCOME, FAMILY OF FOUR, VARIOUS INCOME LEVELS

$\begin{array}{rccrr}\begin{array}{c}\text { Income } \\ \text { before tax } \\ \text { and credits }\end{array} & \text { Credits } & \begin{array}{c}\text { Gross tax } \\ \text { (20 percent } \\ \text { proportionate } \\ \text { rate) } \\ (\text { dollars })\end{array} & \begin{array}{c}\text { Net benefit } \\ \text { or tax (-) }\end{array} & \begin{array}{c}\text { Disposable } \\ \text { income }\end{array} \\ 0 & 1,400 & 0 & 1,400 & 1,400 \\ 1,000 & 1,400 & 200 & 1,200 & 2,200 \\ 2,000 & 1,400 & 400 & 1,000 & 3,000 \\ 3,000 & 1,400 & 600 & 800 & 3,800 \\ 5,000 & 1,400 & 1,000 & 400 & 5,400 \\ 7,000 & 1,400 & 1,400 & 0 & 7,000 \\ 10,000 & 1,400 & 2,000 & -r 600 & 9,400 \\ 20,000 & 1,400 & 4,000 & -2,600 & 17,400 \\ 50,000 & 1,400 & 10,000 & -8,600 & 41,400 \\ 100.000 & 1,400 & 20,000 & -18,600 & 81,400 \\ 200,000 & 1,400 & 40,000 & -38,600 & 161,400\end{array}$

33. See text accompanying note 3 supra. 
net tax is paid that approaches but never quite reaches an average effective rate of 20 percent. Fairly steep progression is achieved through the relevant range by means of the credit, while the marginal rate is constant at 20 percent throughout the income scale.

The credit income tax would achieve vast simplification of the income tax by doing away with the differential treatment of income that is now provided on the basis of differences in sources and disposition, timing of receipts, splitting among taxpaying units, including trusts and minor children, and so forth. Improvements in terms of horizontal equity and efficiency in resource allocation are obvious consequences. If the income base is defined so as to include capital gains in full, including gains constructively realized upon gratuitous transfer of assets, presently exempt interest, social security and related benefits, and imputed net rental income on owner-occupied homes, and if depletion charges were limited to historical cost, few glaring inequities would remain. Moreover, it is even likely that vertical equity, defined in terms of egalitarian objectives, would be better served as well. And, as described, the credit income tax would not provide incentives to break up families.

Obviously, however, the scheme would involve a major redistribution of tax liabilities, particularly toward those whose incomes are now wholly or partially exempt, or who are entitled to large nonbusiness deductions. This clearly suggests that reform on as bold a scale as is here indicated would face extremely difficult political obstacles. If the present income tax base were to survive the reform effort, a proportionate tax rate of about 40 percent would be needed. This might not be an excessively high price to pay in exchange for the gains made available to low-income families and individuals, but it would mean sharply higher taxes in the upper middle income range. ${ }^{34}$ Compromises are clearly possible. A credit income tax need not require an "ideal" income tax base; in fact, one that would include all imputed income and even place a value on leisure is undoubtedly not administratively feasible. Nor is there anything at all sacrosanct about the suggested size of the credit-it might be substantially higher or even lower. But, given the net revenue

34. For example, a family of four witb adjusted gross income of $\$ 10,000$ would pay about $\$ 830$ under present law, $\$ 600$ under the credit income tax illustrated, and $\$ 620$ if the present tax base were retained but a credit of $\$ 400$ per adult and $\$ 300$ per cbild were introduced and a proportionate tax rate of 40 percent were to replace the present rate structure. But for a family having $\$ 20,000$ adjusted gross income, the tax liability, now at $\$ 2,910$, would more than double, to $\$ 5,840$, compared with $\$ 2,600$ under the Rolph-type plan. (Calculations of tax liability under present law assume nonbusiness deductions of 15 percent of adjusted gross income and ignore the temporary surtax). 
objective, there is an inescapable interdependence between the definition of the tax base, the amount of the credit, and the required tax rate. If the Administration or the Congress pursues the scheme it will need to establish acceptable limits with respect to all three variables and present alternative sets of values within the limits.

\section{B. The "Standard" Negative Income Tax}

The credit income tax is, of course, but one of a "family" of negative-type income taxes. Such proposals provide a minimum allowance or credit which establishes the lowest income that any individual or family with no other income may have, at the same time imposing a tax on other income over and above the regular income tax. Typically they retain the existing individual income tax, with or without reform of the base, and allow the taxpayer to elect not to receive the basic allowance when it, coupled with his offsetting tax, produces a negative net benefit. The Tobin-Pechman-Mieszkowski negative income tax proposals ${ }^{35}$ provide for alternative high and low schedules of basic allowances and the option of a 50 or $331 / 3$ percent offsetting tax rate. For illustrative purposes we shall consider their high schedule coupled with a 50 percent tax rate. The basic allowance, which is the income received by an individual or family with no income from other sources, is $\$ 800$ for a single adult, $\$ 1,600$ for a two-adult family, $\$ 2,100$ for three persons ( $\$ 1,800$ if only one adult), $\$ 2,600$ for four persons $(\$ 2,300$ if only one adult), an additional $\$ 400$ for each of the fifth and sixth persons and $\$ 200$ for the seventh and eighth. The maximum allowance is, therefore, $\$ 3,800$, irrespective of family size. With the 50 percent offsetting tax, when other income is equal to double the amount of the basic allowance the "break-even point" is reached. The effect is the same as if no allowance had been received and no taxes paid. At somewhat higher income levels, ranging from $\$ 1,876$ for one person to $\$ 8,359$ for a two-adult, eight-person family, the tax break-even point is reached. At or above this point the individual or family is better off not receiving the allowance, not paying the offsetting tax, and simply paying the regular income tax.

The effects of the Tobin-Pechman-Mieszkowski high allowance plan with a 50 percent offsetting tax rate are presented in Table 4 for families of two, four, and six persons. When other income is zero the basic allowance provides a minimum income of $\$ 1,600, \$ 2,600$, or $\$ 3,400$, amounts which equal roughly three-quarters of the poverty line income for nonfarm families headed by a male adult. In each case

35. Tobin, Pechman and Mieszkowski, supra note 20, at 4-6. 
it takes between $\$ 1,000$ and $\$ 2,000$ of other income to close the poverty gap, the amount increasing with the size of the family. Unlike the Rolph-type credit income tax, the Tobin-Pechman-Mieszkowski plan imposes heavy budgetary demands. Its cost is estimated at $\$ 26$ billion before taking into account the revenue gained from including social security benefits, veterans' pensions, unemployment compensation, imputed rental income on owner-occupied homes, the value of food consumed on farms, a fraction of gifts received, exempt interest, and other items in the negative income tax base, and before calculating the savings of a large part of public assistance costs. The net cost is expected to be about $\$ 20$ billion. ${ }^{36}$ The income base for the offsetting tax would be radically different from the positive income tax base. As indicated, the offsetting tax, but not the ordinary income tax, would apply to a wide range of sources of income excluded from the concept of adjusted gross income, and exemptions and nonbusiness deductions would not be allowed for purposes of the negative income tax.

Under both the credit income tax and the Tobin-PechmanMieszkowski-type negative income tax it would seem fairly simple to provide for monthly or biweekly distributions of payments to those who expect to receive net benefits. Both plans appear to be entirely workable, but both may be expected to encounter formidable political opposition. The negative income tax, at the level of benefits suggested, involves a major budgetary commitment, one that can readily be scaled down, but only at the expense of making the plan inadequate as a means of alleviating poverty. It will be argued as well that it would provide a strong incentive to break up families. For example, a family of two adults and six children would, if they had no other income, receive benefits of $\$ 3,800$, compared with $\$ 4,600$, or $\$ 800$ more, if they split into two families of four. The authors appear correct, however, in their contention that "Amounts of this size do not seem to be large in coniparison with the other considerations that are ordinarily significant in the decision to maintain or split a family unit. ' ${ }^{37}$ The Iogic of that part of the proposal denying any benefits to children beyond the sixth appears more questionable. This provision is designed to give some incentive to limit family size. The obvious response to this is that "other considerations that are ordinarily significant in the decision" 38 determining family size are likely to outweigh the desire to gain an extra $\$ 200$ (the incremental allowance

36. Id. at $24-26$.

37. Id. at 9 .

38. Id. 


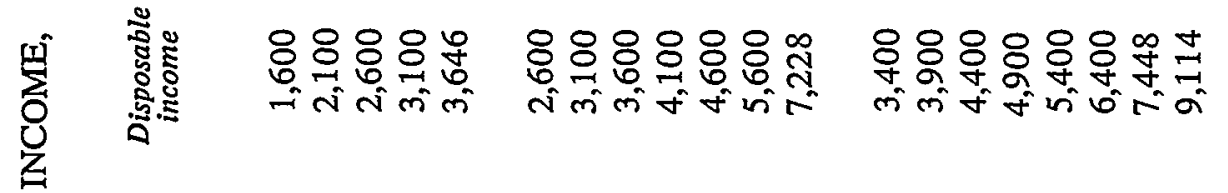

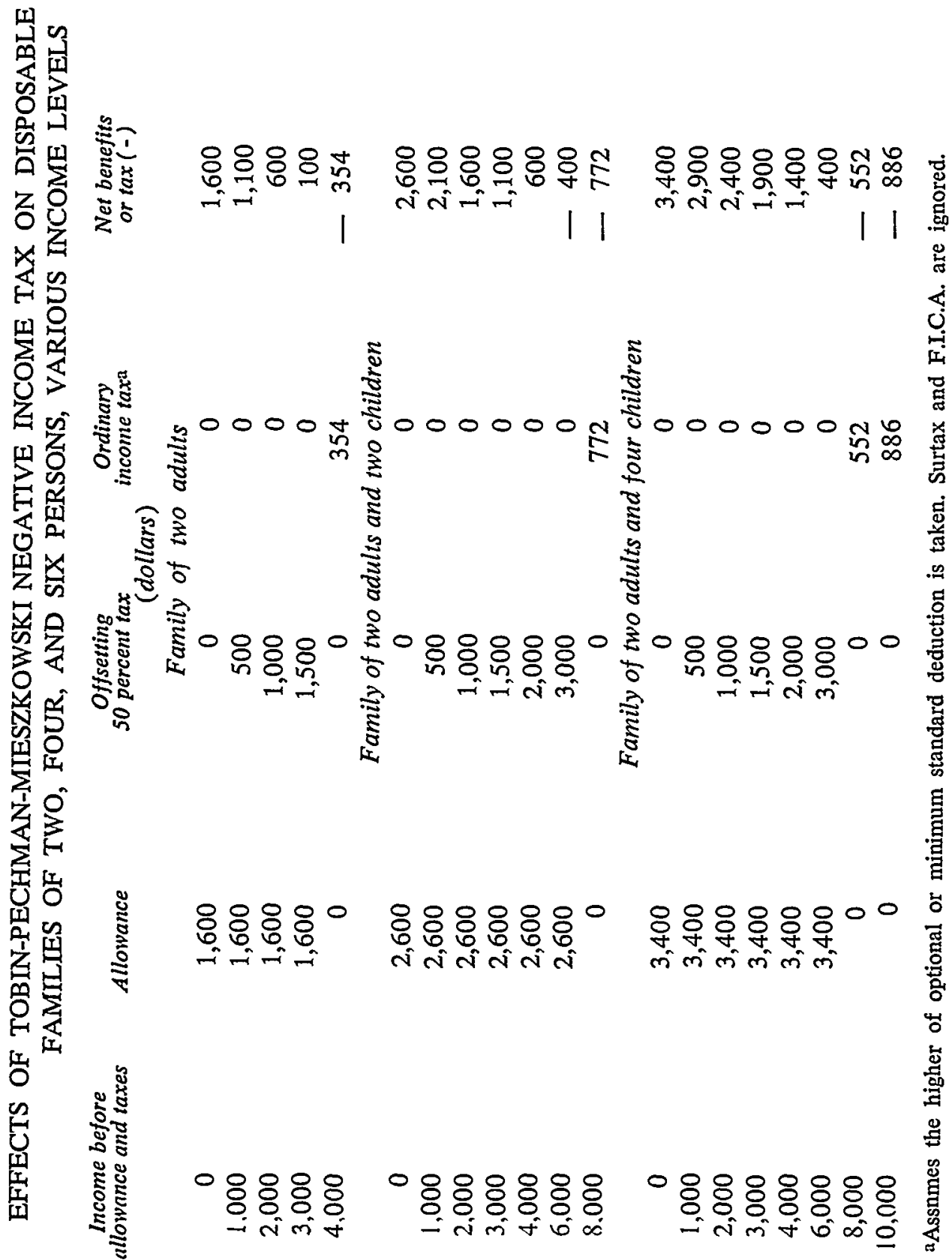


for the fifth and sixth child) by having an additional child. Moreover, and far more important in the short run, is the fact that children already living in families of more than eight persons are far more likely to be impoverished than are children in smaller families. ${ }^{39}$

\section{The Children's Allowance}

If the budgetary demands of the negative income tax impose a major barrier to its acceptance, and if the opposition of those who view the proposal as a threat to the social security system or to continued privileged treatment of various forms of income is insurmountable, a well designed children's allowance plan could provide an attractive and feasible alternative. ${ }^{ \pm 0}$ The social security system, with appropriate amendments, can readily be made into an effective instrument for alleviating or even eliminating poverty among the aged and the disabled. Federalization of the unemployment compensation system, together with extension of the benefit period and improvement in the level of benefits, plus integration of the system with ongoing and improved manpower training programs, could take care of another large part of the population counted as poor. The remainder of the poor population would then consist largely of the working poor who are poor because their earnings are too small to support, even at minimum standards, the number of children dependent upon them, and members of families headed by a female who is not a breadwinner. The case for focusing a major part of antipoverty efforts on the needs of children has been well stated by Professor Tobin:

The acute problem is the inability of many employable males to earn enough to support their children. The result is usually a family in poverty unrelieved by public assistance. With increasing frequency, hovsever, the mother and children are lelt on their own and "go on welfare.' The basic solution in the long run is to build up earning capacities by education and work experience. Meanwhile, people are

39. In 1966 the proportion of families that were poor was more than twice as great for families with six or more children than for families with four children. Orshansky, The Shape of Poverty in 1966. Social Secuity Bull. March 1968, at 19.

40. Most advocates of children's allowances favor universal allowances of modest amount such as are found in virtually every industrialized nation in the world except the United States. See, e.g.. J. VAdakin, Children, Poverty, and Fanily Allowances 183-200 (1968), for a description of children's allowances and advocacy of a plan to distribute $\$ 10$ per month per child under age 18 to all families in the United States. But a plan of this kind can be no more than a minor palliative, although if the allowance were set at the level of $\$ 10$ per month per child the cost would be about $\$ 7.3$ billion per year. $1 d$. at 197 . Far preferable, it seems, is a children's allowance plan under which, at no greater budgetary cost, much higher benefits are made available to the poor within the framework of a universal system. 
poor and their children are raised under handicaps that may destine them to be poor too."1

The children's allowance plan has three essential elements. The present exemption for dependent children under the individual income $\operatorname{tax}^{12}$ would be discontinued. It is essentially a children's allowance that carries a value ranging from $\$ 0$ for those at the bottom of the income scale to $\$ 420$ for those at the top..$^{\$ 3}$ The second element consists of a children's allowance of $\$ 1,400$ for the first child, $\$ 900$ for the second, $\$ 600$ for the third, and $\$ 400$ for the fourth and subsequent children. These allowances would not be included in taxable income, but they would give rise to a "children's allowance tax" (CATAX) so structured as to be a function of other income and the number of children in the family. The base of the CATAX would be adjusted gross income as presently defined. The tax schedule applicable to a two-adult family, with rates ranging from 15 to 56 percent, is set forth in Table 5.4 The major constraint imposed in the construction of the schedule is that for a taxpayer with up to four children the combined marginal tax rate, including CATAX, income tax, and social security tax, is not permitted to exceed 65 percent for all but very high income taxpayers. The CATAX reaches a maximum total equal to 95 percent of the amount of children's allowances received. Thus the effect is to provide credits for children, in lieu of the present exemptions, in amounts that range from $\$ 1,400$ to $\$ 70$ for the first child, $\$ 900$ to $\$ 45$ for the second, $\$ 600$ to $\$ 30$ for the third, and $\$ 400$ to $\$ 20$ for the fourth and all additional children beyond the fourth. The full allowances are retained only when other income is $\$ 0$, while the minimum net allowance applies when other income is $\$ 8,000$ or more. When the additional income tax attributable to the discontinuation of the dependents' exemptions is taken into account, however, the actual net change in after-tax income ranges from gains equal to the full amount of the allowances to reductions that reach maximum levels of $\$ 350, \$ 375, \$ 390$, and $\$ 400$ when the marginal income tax rate is 70 percent. The break-even point is reached when adjusted gross income is approximately $\$ 7,450$ for a faimily of two adults and two children. It is somewhat higher for a family with one child and lower for larger families.

41. Tobin, supra note 8 , at 114 (italics added).

42. INT. Rev. CoDE of 1954, § 151.

43. The tax saving attributable to the exemption ranges from $\$ 0$ when the marginal tax rate is zero to $\$ 420$ when the marginal tax rate reaches 70 percent.

44. A second schedule is required for one-adult families. It takes account of the higher income tax rates paid by "heads of households" and thus provides for somewhat lower CATAX rates. 


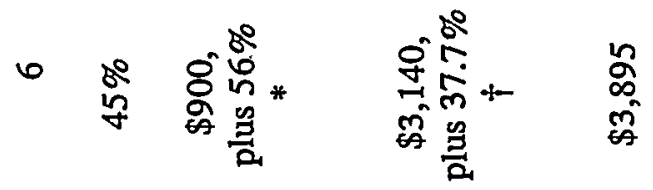

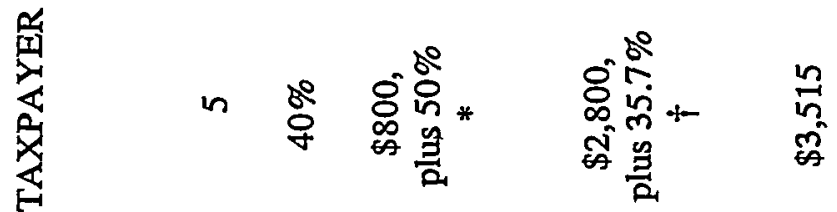

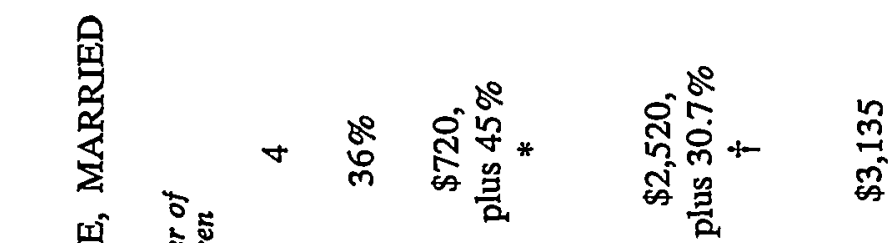

$$
\begin{aligned}
& \text { n }
\end{aligned}
$$

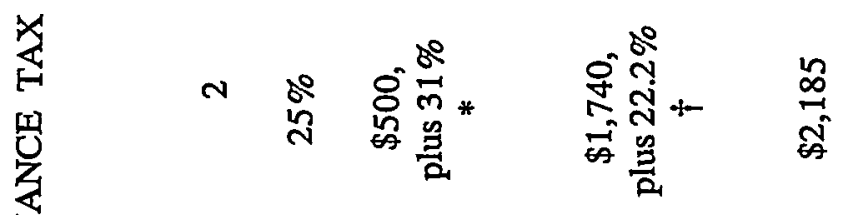

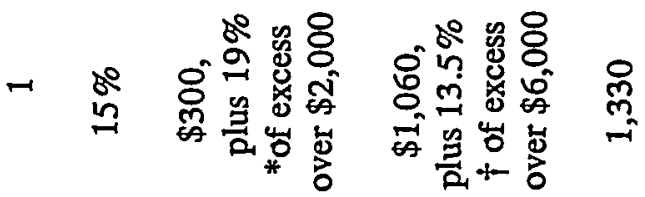

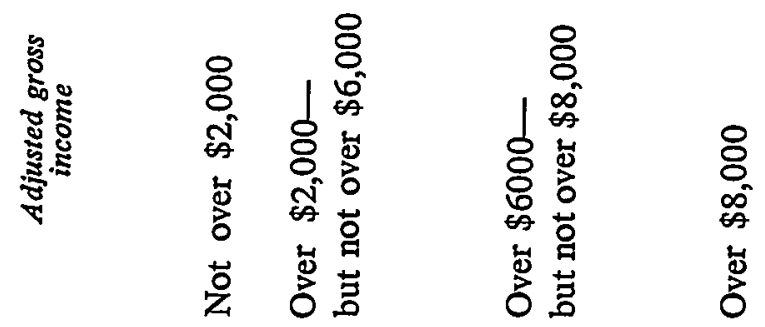


The operation of the plan is illustrated in Table 6 for two-adult families with one, two, and four children, with other incomes ranging from $\$ 0$ to $\$ 10,000$. In the case of the one-child family with no other income the allowance of $\$ 1,400$ is equal to 54 percent of poverty line income for a nonfarm family of three. At $\$ 2,300$ for a family of four 69 percent of poverty line income is received. For a family of six, three-quarters of the poverty gap is removed, and that proportion is approximately maintained for larger families. When other income exceeds zero the net allowances fill increasingly large proportions of the poverty gap and bring a substantial fraction of all poor families above the poverty line. In the case of a family with two children and other income of $\$ 1,000$, for example, the initial poverty gap of $\$ 2,335$ is reduced to $\$ 285$, or by almost 88 percent, and when other income reaches $\$ 2,000$ and the net allowances raise disposable income to $\$ 3,772$, or $\$ 437$ above the poverty line. Net benefits decline as other income rises, the implicit marginal tax rates approaching 65 percent and then falling off to equal the marginal individual tax rate when adjusted gross income is $\$ 8,000$, the point at which the marginal CATAX becomes zero. Gains continue to be realized until other income exceeds $\$ 7,000$, so that the program assists not only the poor but low-income families generally.

Estimates based on data supplied by the Social Security Administration provide interesting insights into the cost components of the program and its impact on poverty among families with dependent children under 18 years of age. The gross cost of the children's allowances is $\$ 68.5$ billion. Of this amount $\$ 7$ billion is recovered in the form of additional income tax revenue resulting from the discontinuation of exemptions for dependent children. The children's allowance tax (CATAX) is estimated to yield $\$ 52.1$ billion, thus reducing the net cost to $\$ 9.4$ billion. If it is assumed that the receipt of children's allowances will reduce AFDC payments dollar for dollar, the reduction in such payments would amount to $\$ 1.8$ billion and the net cost of the program to all levels of government would be $\$ 7.6$ billion. For federal budgetary purposes the cost would be about $\$ 8.6$ billion, while state and local governments would save approximately $\$ 800$ million.

The total poverty gap for families with children is estimated at $\$ 6.2$ billion for 1966. Some 13 million children, members of over 4 million families, lived in poverty in that year. The children's allowance program outlined here, if it had been in effect in 1966, would have reduced the poverty gap for families with children by 81 percent and more than half of all poor children would have been lifted 


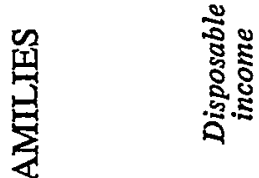

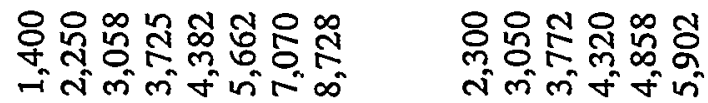

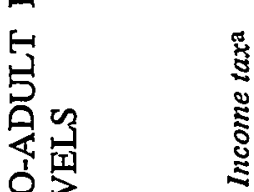

I

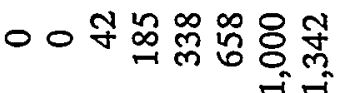

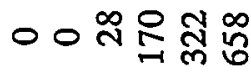

空至

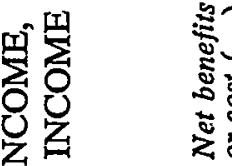

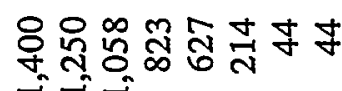

11

융ํㅠ윯유ำ तiनi

ש

됭응

$\equiv 3$

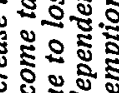

:

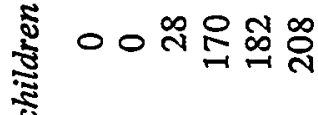

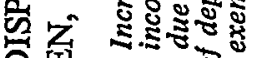

量

杂合

a

떵오

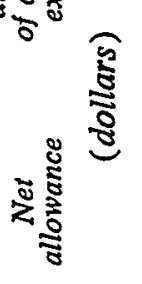

ธั

악육역역옹융요

立

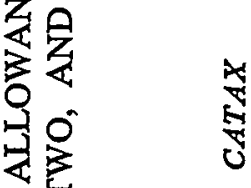

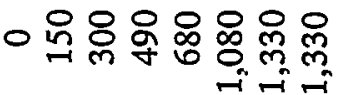

앳윰옹웍웓

至至

占

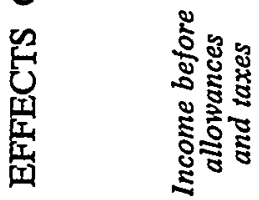

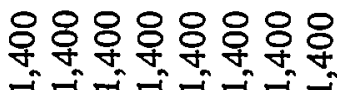

일융요용

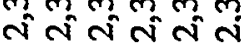

-

○ 88888 


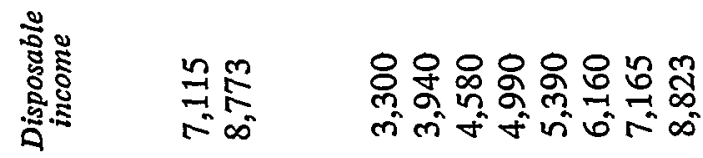

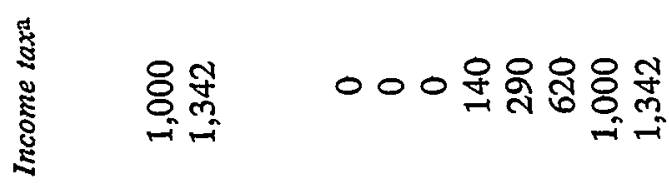

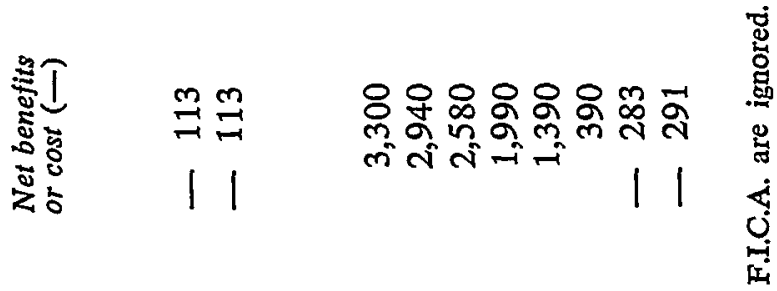

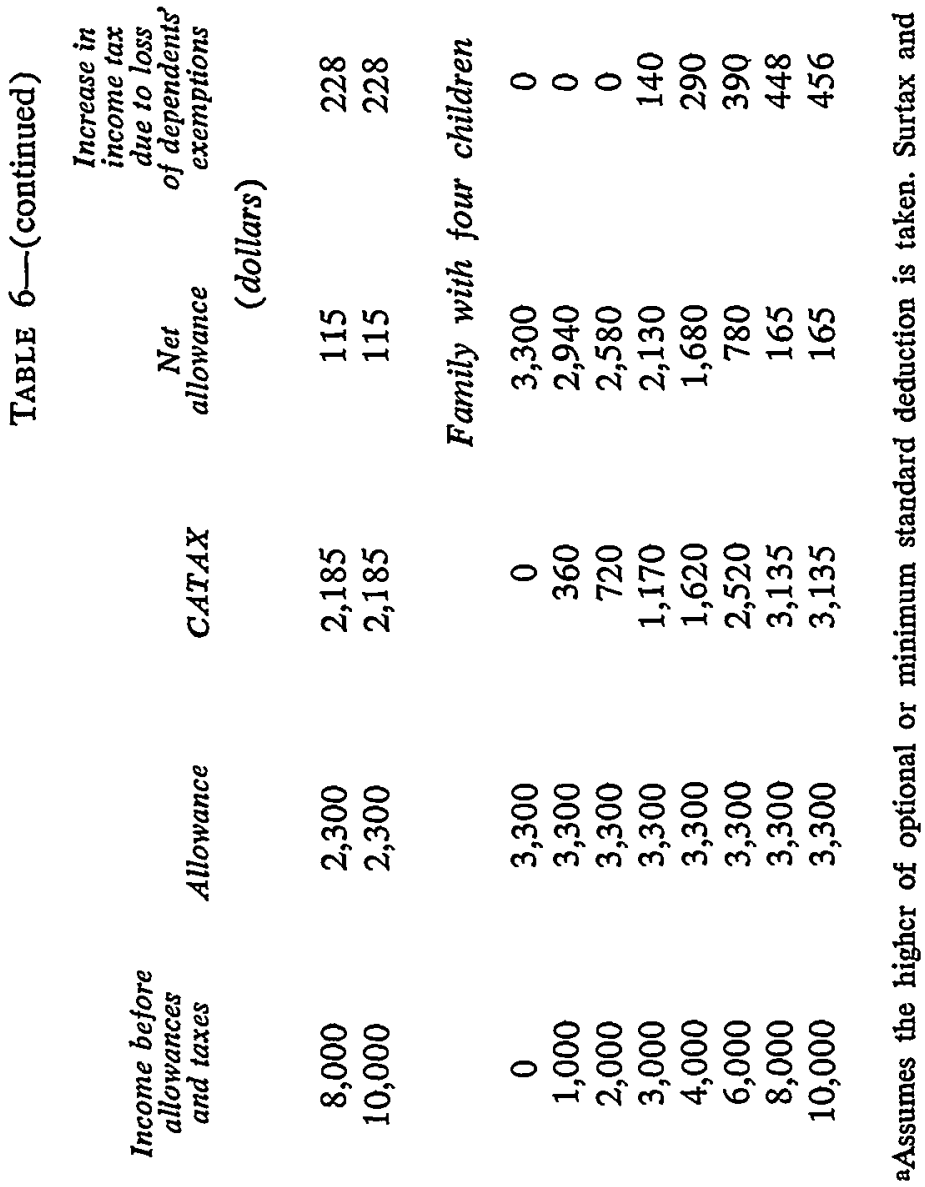


out of poverty. Moreover, at the net cost of $\$ 7.6$ billion, the disposable income of those who were initially poor would have been increased by $\$ 6.4$ billion, or 84 percent of the net increase in the disposable income of all families. The $\$ 6.4$ billion represents an increase of more than 70 percent in the income of those who were initially poor. Thus the program appears to satisfy the test of "efficiency,"15 in the sense that the net benefits are heavily concentrated among the poor. At the same time marginal tax rates, especially for smaller families (one and two children) are not so high as to discourage work effort. While they do exceed 65 percent for high income families with more than four children, incentives to work outside the home, in the case of families headed by a female, are unlikely to be strong under any circumstances. For families headed by a male, incentives to work are not likely to be dependent on marginal tax rates as long as such rates are substantially below 100 percent.

Administration of the program would not present major difficulties. All families with children would receive children's allowance checks once or twice a month and the CATAX can readily be built into withholding schedules. Those whose incomes are not subject to withholding would be expected to report and pay the CATAX along with their quarterly payments of income tax. Verification of the number and eligibility of children and of income would fit readily into a somewhat enlarged Internal Revenue Service audit program. The force of incentives to break up families would be somewhat stronger than under the Tobin-Pechman-Mieszkowski negative income tax plan. ${ }^{46}$ if this were regarded as a major problem the differential in. the allowances for successive numbers of children could be reduced. But this would place serious hardships on one- and two-child families. On balance it seems preferable to rely on the dominance of other factors governing decisions as to family unity.

Another issue that arises involves the relationship between aid to families with dependent children and the proposed children's allowances. At most this issue concerns only the one-third of all poor children who are now beneficiaries under AFDC. ${ }^{47}$ For them the children's allowance benefits suggested are substantially larger than AFDC payments per child in all but one-quarter of the states. ${ }^{48}$ The

45. See text accompanying note 19 supra.

46. For example, a family with six children would receive gross allowances in the amount of $\$ 4,100$, whereas two families with three children would each receive $\$ 2,900$. Thus splitting the large family in two would yield a gain of $\$ 1,700$ if no other income were received. 20.

47. Orshansky, The Shape of Poverty in 1966, Social Security Bull. March 1968, at

48. See Social Security Bull. November 1968, at 44. 
most appealing approach is one that would permit the states to supplement children's allowances under continued federal aid. The children's allowances would then establish a floor under support levels available to families with children, one that would reduce drastically the influence of state residence on the welfare of children.99

The. children's allowance proposal, being essentially a proposal for a negative income tax confined to families with dependent children, necessarily encounters the same kinds of problems with respect to the definition of income subject to the offsetting tax that so much concerned Tobin et al. Because the aged would rarely be affected, social security benefits and other nontaxable pensions received by them are not at issue. But almost 3 million children do receive survivors' benefits under OASDHI, and all other excludable income, such as municipal bond interest, imputed rental income on owner-occupied homes, food consumed on the farm, half of long term capital gains, and unemployment compensation, should, ideally, be taken into account in arriving at net benefits. Otherwise inequities obviously would arise as between renters and homeowners, for example, inequities that, given the relatively high marginal rates required under the CATAX, are more serious than those presently in existence under the income tax. The added complexities in compliance and administration that would ensue must be considered together with the desirability of a comprehensive redefinition of income for purposes of the CATAX. It seems advisable to accept the inequities with respect to the CATAX until or unless the Congress is willing to remove them and adopt a comprehensive income tax base. This is, of course, a matter for political judgment.

\section{CONCLUSION}

The individual income tax does not presently serve as a major instrument for redistribution of income. Nor is it capable, in its present form, of providing substantial help for the near-poor. For those who are living in poverty the income tax can assume significance only by incorporating a substantial negative element. The negative factor would enable the government to make payments to people having very low or zero incomes and it would reduce appreciably the net contribution to the Treasury of many with incomes that are low but above the poverty line as defined by the Social Security Administra-

49. Average monthly payments per child now range from as Iow as $\$ 9.42$ and $\$ 10.34$ in Puerto Rico and Mississippi to $\$ 77.09$ in New Jersey and $\$ 96.96$ in New York. Derived from Social Security Bull. Nov. 1968, at 44. 
tion. Once this general approach is accepted in principle, and the income tax extended so that it provides for net payments to part of the population as well as demanding upwards of $\$ 80$ billion per year from its more affluent members, it can become a major means of alleviating or even eliminating poverty and deprivation. Education, training, work experience, the elimination of racial barriers to jobs, and access for all to decent housing and health services are undoubtedly the prerequisites for any ultimate solution to the problem of poverty in an affluent nation. But income maintenance programs will always be needed for some groups in the population, and the poor are no longer complacent about being poor while awaiting the results of programs designed to raise their earning capacities. For some, such as female heads of large families and male family heads with limited abilities to acquire the skills needed to enable them to escape poverty, such efforts are likely to bring results only in the next generation. There can be hope for that next generation only if, while growing up, it is supported by a level of income that will insure decent nutrition, adequate housing, protection of health, and some sense of dignity.

As a benevolent dictator, one would be strongly moved toward adoption of a credit income tax with credits set high enough to remove substantially more than half of the total poverty gap of about $\$ 11$ billion, but not so high as to dissuade large numbers of people from seeking gainful employment. The credit income tax, however, seems a long way off in a representative democracy. 1ts prospects are poor in the political arena because it encroaches on strongly entrenched vested interests; presently allowed exclusions and deductions would have to be abolished in order to broaden the tax base sufficiently to permit the tax rate to remain within reasonable bounds.

The negative income tax of the kind advocated by Tobin, Pechman, and Mieszkowski is far less radical than the credit tax, but it too may demand too much, in terms of budgetary costs and the authors' insistence on including major elements of income in the base of the offsetting tax which presently represent privileged exclusions.

Both the credit income tax and the negative income tax could be made more acceptable from a political standpoint if the credit or basic allowances were offered at very low levels while, at least initially, a narrower tax base was adopted. But this approach would offer far more than it is capable of delivering. It would not permit discontinuation of any of the public assistance programs that now accentuate the affliction of poverty. And at the same time it could once more lead to the frustration of thwarted expectations. 
If recourse must be had to a modest program, a children's allowance of the dimensions and properties described above has enormous appeal. It requires only a comparatively minor change in the individual income tax. The exemptions for dependent children need simply be replaced by what amounts to a dependents' credit that varies inversely with the number of children in the family and income. Instead of the accretion to after-tax income resulting from the dependents' exemption, which varies in amount from nothing at very low income levels to as much as $\$ 420$ at the highest levels of income, the combined children's allowance and children's allowance tax would add as much as $\$ 1,400$ to income at the lowest level and as little as $\$ 20$ (for the fourth and succeeding children) through the middle and high range of the income scale.

The children's allowance approach gains its appeal in part from the fact that children constitute the largest unaided portion of the existing poor population. Existing social security and unemployment compensation programs are capable, if appropriately improved, of alleviating poverty among the aged, the disabled, and the unemployed. But programs of education and training aimed at breaking the cycle of intergenerational transmission of poverty are doomed to failure if the children to be educated are without adequate food, clothing, shelter, and health services and are living under circumstances that cannot foster hope, dignity, or pride. 